\title{
A Literature Review of Mergers and Acquisitions
}

\author{
Dr.S.NIRMALA ${ }^{1}$, ARUNA.G ${ }^{2}$ \\ ${ }^{1}$ Associate professor and Head (Business Management), \\ PSGR Krishnammal College for Women, Coimbatore \\ nirjaya@rediffmail.com \\ ${ }^{2} \mathrm{PhD}$ Research Scholar (Business management), \\ PSGR Krishnammal College for Women, Coimbatore. \\ arunamgt@gmail.com
}

\section{ABSTRACT}

An extensive review of literature has been carried out in order to get a good understanding in the topic of Mergers and Acquisitions. Literature review has been done from books, journal, published papers etc.The issues covered include Motives, Share value creation, Financial performance, operating performance. These studies have been reviewed and presented in the following manner. Literature review has been collected from both within India and outside India.

KEYWORDS: Mergers and Acquisitions, Motives, Share value creation, Financial performance

\section{Academic Discipline and Sub-Disciplines}

Management

\section{SUBJECT CLASSIFICATION}

Mergers and Acquisitions

\section{TYPE (METHOD/APPROACH)}

Review of Literature which is based on secondary source of data available from Books, Journals and Papers published

\section{Council for Innovative Research}

Peer Review Research Publishing System

Journal: International Journal of Management \& Information Technology

\author{
Vol. 5, No. 1 \\ editor@cirworld.com \\ www.cirworld.com, member.cirworld.com
}




\section{INTRODUCTION}

Mergers and Acquisitions (M\&A) are being increasingly used the world over, for improving competitiveness of companies through gaining greater market share, broadening the portfolio to reduce business risk, for entering new markets and geographies, and capitalising on economies of scale etc.Merger and acquisition for long have been an important phenomenon in the US and UK economics. In India also, they have now become a matter of everyday occurrence. They are the subject of counting interest to different persons such as the business executives who are looking for potential merger partners, investment bankers who manage the mergers, lawyers who advice the parties, regulatory authorities concern with the operations of stock market and growing corporate sectors in the economy and researchers who want to understand these concepts better.

\section{REVIEW OF LITERATURE}

The following were the major efforts at research in the subject, which have been referred for the research purpose.

P Akhil Bhan ${ }^{1}$ has made an attempt to study the insight into the motives and benefits of the mergers in Indian banking sector. This is done by examining the eight merger deals of the banks in India during the period of reforms from 1999 to 2006. Through the empirical methods by applying t-test and EVA value calculations the potential of the mergers has been evaluate to study the efficiencies or benefits achieved due to the merger. Through this paper and the sample taken for analysis it has been concluded that the mergers in the banking sector in the post reform period possessed considerable gains which was justified by the EVA of the banks in the post merger period.

Dr. V. K. Shobhana and Dr. N. Deepa $(\mathbf{2 0 1 1})^{2}$ made a probe into the fulfilment of motives as vowed in the merger deals of the nine select merged banks. The study uses Summary Statistics, Wilcoxon Matched Paired Signed Rank Test and't' test for analysis and interpretation of data pertaining to the five pre and post merger periods each. The result indicates that there has been only partial fulfilment of the motives as envisaged in the merger deals

Egl Duksait and Rima Tamosiunien (2009) ${ }^{3}$ described the most common motives for companies decision to participate in mergers and acquisitions transactions. The reason is growth, synergy, access to intangible assets, diversification, horizontal and vertical integration and so on arises from the primary company's motive to grow. Most of the motivations for mergers and acquisitions feature serve as means of reshaping competitive advantage within their respective industries. However, it may be that some of the motives identified affect some industries more than others, and in that sense they can be expected to be associated with a greater intensity of mergers and acquisitions in certain sectors rather than others.

Ms. Astha Dewan (2007) ${ }^{4}$ focussed on the post merger financial performance of the acquirer companies in India and performance of firms going through mergers in Indian industry. The merger cases for the year 2003 have been taken for the analysis. The financial data has been collected for six years from 2000-06. Pre-merger and post-merger financial ratios have been examined using paired sample t test. The results of the analysis reveal that there is significant difference between the financial performance of the companies before and after the merger. Further, it has been found that the type of industry does seem to make a difference to the post-merger operating performance of acquiring firms

Mital Menapara et al ${ }^{5}$ evaluated the impact of mergers and acquisitions on financial Performance of Indian Corporate Sectors and examined the impact of merger and acquisitions on Return on Investment, Profitability and Liquidity position of selected companies. The authors concluded that emerging from the point of view financial evaluation is that the merging Companies were taken over by companies with reputed and good management. And therefore, it was possible for the merged firms to turnaround successfully in due course.

Pramod Mantravadi \& A Vidyadhar Reddy (2008) ${ }^{6}$ studied the impact of mergers on the operating performance of acquiring corporates in different industries, by examining some pre- merger and post-merger financial ratios, with the sample of firms chosen as all mergers involving public limited and traded companies in India between 1991 and 2003 . The results from the analysis of pre- and post- merger operating performance ratios for the acquiring firms in the sample showed that there was a differential impact of mergers, for different industry sectors in India. Type of industry does seem to make a difference to the post-merger operating performance of acquiring firms.

Jagdish R. Raiyani $(\mathbf{2 0 1 0})^{\mathbf{7}}$ in her study investigated the extent to which mergers lead to efficiency. The financial performance of the bank has been examined by analyzing data relevant to the select indicators for five years before the merger and five years after the merger. It is found that the private sector merged banks are dominating over the public sector merged banks in profitability and liquidity but in case of capital adequacy, the results are contrary. Further, it was observed that the private sector merged banks performed well as compared to the public sector merged banks

Rehana Kouser and Irum Saba (2011) ${ }^{8}$ explored the effects of merger on profitability of the bank by using six different financial ratios. They have selected 10 commercial banks that faced M\&A during the period from 1999 to 2010 . The lists of banks were selected from the Karachi Stock Exchange (KSE). Quantitative data analysis techniques are used for inference. Analysis was done by using paired t-test. The results recommend that operating financial performance of all commercial bank's M\&A included in the sample from banking industry had declined later. The results shows that there is a decline in all 6 ratios: profitability ratios, return on net worth ratios, invested capital, and debt to equity ratios.

Dr. Neena Sinha et al (2010) ${ }^{9}$ in their study described the impact of mergers and acquisitions on the financial efficiency of the selected financial institutions in India. The analysis consists of two stages. Firstly, by using the ratio analysis approach, they calculated the change in the position of the companies during the period 2000-2008. Secondly, they 
examine changes in the efficiency of the companies during the pre and post merger periods by using nonparametric Wilcoxon signed rank test. The result revealed a significant change in the earnings of the shareholders, there is no significant change in liquidity position of the firms. The result of the study indicate that M\&A cases in India show a significant correlation between financial performance and the M\&A deal, in the long run, and the acquiring firms were able to generate value

Nisarg A Joshi and Jay M Desai ${ }^{10}$ in their study measured the operating performance and shareholder value of acquiring companies and comparing their performance before and after the merger. They used Operating Profit Margin, Gross Operating Margin, Net Profit Margin, Return on Capital Employed, Return on Net Worth, Debt-Equity Ratio, and EPS P/E for studying the impact. They concluded that as in previous studies, mergers do not improve performance at least in the immediate short term.

Pramod Mantravadi, A.Vidyadhar Reddy (2007) ${ }^{11}$ in their research paper focussed on the impact of mergers on the relative size and operating performance of acquiring corporates by examining some pre- and post-merger financial ratios with a sample of firms chosen from all mergers involving public limited and traded companies in India between 1991 and 2003. The study used the following financial ratios: operating profit margin, gross profit margin, net profit margin, return on net worth return on capital employed and debt-equity ratio. The results suggest that there are minor variations in terms of the impact on operating performance following mergers, when the acquiring and acquired firms are of different relative sizes, as measured by market value of equity.

Julie Lei Zhu (2011) ${ }^{12}$ developed a new measure for shareholder value creation to assess the efficiency of acquiring firms in utilizing capital before mergers and acquisitions (M\&As) and links this measure to acquirers' post-acquisition performance. His measure, constructed before the M\&A transaction, (a) predicts both the operating and long-run abnormal stock performance of merged firms after the acquisitions and (b) hedge portfolios based on the measure generate substantial abnormal returns. Overall, the results indicated that investors do not fully recognize how efficient acquirers have been in utilizing capital before M\&As and that incorporating the new value creation measure into the decision process of large-scale M\&As can help protect shareholder wealth.

Mehroz Nida Dilshad (2012) ${ }^{13}$ measured the efficiency of market with respect to announcements of mergers and acquisitions using an event study methodology. The study analyzed the effects of banks mergers and their announcements on the prices of stocks, in Europe. Evidence here supports that significant cumulative abnormal returns were short lived for the acquirers. At the end of the event window, the cumulative abnormal returns were 0 . Evidence of excess returns after the merger announcement was also observed along with the leakage of information that resulted in the rise of stock prices few days before the announcement of merger or acquisition. At the same time, the results of cumulative abnormal returns showed that target banks earned abnormal returns on the merger announcement day.

A. Bashir et al (2011) ${ }^{\mathbf{1 4}}$ investigated the performance record of forty five mergers and acquisitions (M\&A) that took place during 2004 to 2010 in various sectors of Pakistan using event study methodology. They indicated that overall during eleven day window period neither target nor acquirer firms created or destroyed value for shareholders. The wealth for the shareholders of target and bidder firms is examined by estimating the cumulative abnormal returns for an 11-day period surrounding the merger announcement. Their findings indicate that overall during eleven day that of acquirer's enjoy statistically insignificant increase in value. Their findings are in disagreement to majority of studies in this area, which indicate the gain to target shareholders while loss to acquired companies.

Annalisa Caruso and Fabrizio Palmucci ${ }^{15}$ analysed the market reaction to M\&A in the banking sector, particularly interesting because of the higher complexity of corporate governance and the importance that the M\&A activity has had in recent years in Europe, especially in Italy. In this research they performed an event study on the Italian market (in the period 1994-2003) with two main goals: first they observe if and when there is a positive value creation, and when private benefits of control represent one of the drivers of the operations; secondly investigated the determinants of their results, looking at the characteristics of the banks, regulation, the role of minority shareholders and that of the Bank of Italy.

Mathieu Luypaert ${ }^{16}$ empirically investigated the industry determinants of shareholder value creation in a sample of horizontal M\&As in Europe during the period 1997-2006. The results show that industry concentration, industry-level operating performance, and the ratio of combined target and bidder size relative to the minimum efficient scale in the corresponding industry are significantly negatively related to the total value creation in M\&As. The relation between industry sales growth and combined value creation is $U$-shaped. We also find some evidence that the value creation in $M \& A s$ is significantly higher in recently deregulated industries. Finally, the data reveal that the distribution of M\&A value between target and bidder investors is determined by firm-level variables rather than by industry characteristics.

Dr. P. Natarajan and k. Kalaichelvan $\mathbf{( 2 0 1 1 )}^{\mathbf{1 7}}$ used the share price data and financial statements of eight select public and private sector banks, during the period between 1995 and 2004, this study examined M\&A as a business strategy and to identify the relative importance of mergers on business performance and increased Shareholders wealth. The study showed that in a banking environment marked by frequent mergers, such transactions directly or indirectly effects the shareholders sentiments and increase market share (i.e.) mergers enhances performance and wealth for both the businesses and shareholders.

Jianyu Ma et al (2009) ${ }^{18}$ investigated abnormal returns to shareholders of bidder firms around the day of M\&A announcement for ten emerging Asian markets: China, India, Hong Kong, Indonesia, Malaysia, the Philippines, Singapore, South Korea, Taiwan, and Thailand. Using a sample of 1,477 M\&A deals in the ten emerging Asian markets, It was found that the stock markets have expected positive cumulative abnormal returns in three different event windows: a two-day (0, 
1) window, a three-day $(-1,+1)$ window, and a five-day $(-2,+2)$ window. Valuation effects of information leakage about M\&A deals are statistically significant. The findings suggest that as investors reap the financial benefits associated with $M \& A$ deals, external growth through M\&A activity may be highly recommended to managers.

Panayiotis Liargovas and Spyridon Repousis (2011) ${ }^{19}$ examined the impact of Greek mergers and acquisitions on the performance of the Greek Banking Sector during the period 1996-2009. With the use of event study methodology, we reject the "semi-strong form" of Efficient Market Hypothesis (EMH) of the Athens Stock Exchange. The overall results indicate that bank mergers and acquisitions have no impact and do not create wealth. They also examined operating performance of the Greek Banking Sector by estimating twenty financial ratios. Findings show that operating performance does not improve, following mergers and acquisitions. There are also controversial results when comparing merged to non-merged banks.

Ahmad Ismail, lan Davidson \& Regina Frank (2009) ${ }^{20}$ concentrated on European banks and investigated post-merger operating performance and found that industry-adjusted mean cash flow return did not significantly change after merger but stayed positive. Also find that low profitability levels, conservative credit policies and good cost-efficiency status before merger are the main determinants of industry-adjusted cash flow returns and provide the source for improving these returns after merger. Results show that total factor productivity for merger banks for the period after merging can be attributed to an increase in technical inefficiency and the disappearance of economies of scale, while technical change remained unchanged compared to the pre-merging level.

George E Halkos \& Dimitrios (2004) ${ }^{21}$ applied non-parametric analytic technique (data envelopment analysis, DEA) in measuring the performance of the Greek banking sector. He proved that data envelopment analysis can be used as either an alternative or complement to ratio analysis for the evaluation of an organization's performance. However, analysis of the causes of failure has often been shallow and the measures of success weak.

Ping-wen Lin (2002) ${ }^{22}$ findings proves that there is a negative correlation and statistical significance exist between cost inefficiency index and bank mergers; meaning banks engaging in mergers tend to improve cost efficiency. However, the data envelopment analysis empirical analysis found that bank mergers did not improve significantly cost efficiency of banks. In another study, he found that (1) generally; bank mergers tend to upgrade the technical efficiency, allocative efficiency, and cost efficiency of banks; however a yearly decline was noted in allocative efficiency and cost efficiency. (2) In terms of technical efficiency and allocative efficiency improvement, the effect of bank mergers was significant; however, in terms of cost efficiency improvement, the effect was insignificant.

Suchismita Mishra, Arun, Gordon and Manfred Peterson (2005) ${ }^{23}$ examined the contribution of the acquired banks in only the non conglomerate types of mergers (i.e., banks with banks), and finds overwhelmingly statistically significant evidence that non conglomerate types of mergers definitely reduce the total as well as the unsystematic risk while having no statistically significant effect on systematic risk. Xiao Weiguo \& Li Ming (2008) paper uses DEA (Data Envelopment Analysis) for analyzing commercial banks' efficiency, top five American banks and four Chinese banks and concluded that merger and acquisition (M\&A) has greater impact on banking efficiency of Chinese banks than that of American banks.

Robert DeYoung (1997) ${ }^{24}$ estimated pre- and post-merger X-inefficiency of mergers. Efficiency improved in only a small majority of mergers, and these gains were unrelated to the acquiring bank's efficiency advantage over its target. Efficiency gains were concentrated in mergers where acquiring banks made frequent acquisitions, suggesting the presence of experience effects. The study examines the efficiency consequences of bank mergers and acquisitions of Australian four major banks. The empirical results demonstrate that for the time being mergers among the four major banks may result in much poorer efficiency performance in the merging banks and the banking sector.

Morris Knapp, Alan Gart \& Mukesh Chaudhry (2006) ${ }^{25}$ research study examines the tendency for serial correlation in bank holding company profitability, finding significant evidence of reversion to the industry mean in profitability. The paper then considers the impact of mean reversion on the evaluation of post-merger performance of bank holding companies. The research concludes that when an adjustment is made for the mean reversion, post-merger results significantly exceed those of the industry in the first 5 years after the merger.

\section{CONCLUSION}

Although there is enough research literature on mergers and acquisitions, most of the studies have been done for the efficient markets of the developed world especially US and UK. In India, very limited research has been done on this topic. Books available are in plenty but they are mostly theory based. None of the few studies conducted in India have explored the performance of mergers and acquisitions empirically in terms of their effect on Performance of Company. The present study makes an attempt to fill these voids and aims to investigate the performance of Pre - Post mergers and acquisitions that have taken place in India.

\section{REFERENCES}

[1] Bhan, B. Y. A. (n.d.). [ MERGERS IN INDIAN BANKING SECTOR - MOTIVES AND BENEFITS

[2] Shobana.V.K and Deepa.N, (2011). Fulfilment of merger motives - evidences from mergers and acquisitions in the Indian Banking Scenario- International Journal of research in Commerce, Economics \& Management- volume no. 1 (2011), issue no. 6 (October) ISSN 2231-4245 
[3] Duksait, E., \& Tamošiūnien, R. (2006). MOKSLAS - LIETUVOS ATEITIS SCIENCE - FUTURE OF LITHUANIA WHY COMPANIES DECIDE TO PARTICIPATE IN MERGERS AND, 2341, 21-25.

[4] Dewan Astha (2007) - Effect of Mergers and Acquisitions on Operating Performance: A Study of Acquiring Firms in India-(Mergers, n.d)

[5] Menpara.Mital.Mergers, O. F. (n.d.). A Study On Financial Performance Of Selected Companies During Pre-Post Merger And Acquisition- Abhinav- Volume No.1, Issue No.11 Issn 2277-1166-pg no 192-198

[6] Performance, C., \& Act, I. T. (1961). Effect of Mergers and Acquisitions on Operating Performance : A Study of Acquiring Firms in India The general rule of corporate synergy signifies that the value created, 1-10.

[7] Raiyani, J. R. (n.d.). Effect of mergers on efficiency and productivity of Indian banks : A CAMELS analysis, 772794.

[8] Saba, I., \& Scholar, P. D. (1974). No Title, 54-64.- EFFECTS OF BUSINESS COMBINATION ON FINANCIAL PERFORMANCE: EVIDENCE FROM PAKISTAN'S BANKING SECTOR- Australian Journal of Business and Management Research Vol.1 No.8 [54-64] | November-2011-pg no 54-64.

[9] Sinha, N. (1967). Measuring Post Merger and Acquisition Performance: An Investigation of Select Financial Sector Organizations in India, (November 2010), 190-200.

[10] Nisarg A Joshi, Jay M Desai. A Study of Mergers \& Acquisitions in Aviation Industry in India and Their Impact on the Operating Performance and Shareholder Wealth- ssrn.com/abstract=2025282.

[11] Mantravadi Pramod \& Reddy .Vidhyadhar.Post-Merger Performance of Acquiring Firms from Different Industries in India- International Research Journal of Finance and Economics-ISSN 1450-2887 Issue 22 (2008)-pg no 192204.

[12] Zhu, J. L. (n.d.). A New Measure for Shareholder Value Creation and the Performance, (November 2011).

[13] Dilshad, M. N. (2013). Profitability Analysis of Mergers and Acquisitions: An Event Study Approach. Business and Economic Research, 3(1). doi:10.5296/ber.v3i1.2781.

[14] Bashir, A., Sajid, M. R., \& Sheikh, S. F. (n.d.). The Impact of Mergers and Acquisitions on Shareholders Wealth : Evidence from Pakistan, 8(1), 261-264.

[15] Caruso, A., \& Palmucci, F. (n.d.). No Title, 1.- Measuring value creation in bank mergers and acquisitions.

[16] Luypaert, M., Huyghebaert, N., Brussel, H., \& Leuven, K. U. (n.d.). Industry Determinants of Shareholder Value Creation in European Horizontal Mergers and Acquisitions.

[17] Natarajan.P and Kalaichelvan. Stock Price Reaction of The Merged Banks - An Event Study ApproachInternational Journal of Research in Commerce \& Management-volume no: 2 (2011), issue no. 4 (April) ISSN 0976-2183.

[18] Ma, J., Pagán, J. A., \& Chu, Y. (n.d.). Abnormal Returns to Mergers and Acquisitions in Ten Asian Stock Markets, 14(3).

[19] Liargovas, P., \& Repousis, S. (2011). The Impact of Mergers and Acquisitions on the Performance of the Greek Banking Sector: An Event Study Approach. International Journal of Economics and Finance, 3(2), 89-100. doi:10.5539/ijef.v3n2p89.

[20] Ahmad Ismail, lan Davidson \& Regina Frank. (2009). Operating performance of European bank mergers. The Service Industries Journal, Vol. 29, Iss. 3, p. 345.

[21] George E Halkos \& Dimitrios S Salamouris. (2004). Efficiency measurement of the Greek commercial banks with the use of financial ratios: a data envelope analysis approach. Management Accounting Research, Vol. 15, ISSN. 2, p. 201-224.

[22] Ping-wen Lin. (2002). The Efficiency of Commercial Bank Mergers in Taiwan: An Envelopment Analysis. International Journal of Management, Vol. 19, ISSN. 2, Part 2, p. 334-342 (9 pp.).

[23] Suchismita Mishra, Arun J Prakash, Gordon V Karels, and Manferd Peterson (2005). Bank Mergers and Components of Risk: An Evaluation. Journal of Economics and Finance, Vol. 29, Is. 1, p. $85-96$ (12 pp.).

[24] Robert DeYoung. (1997). Bank mergers, x-efficiency, and the market for corporate control. Managerial Finance, Vol. 23, ISSN. 1, p. 32-47 (18 pp.).

[25] Morris Knapp, Alan Gart, and Mukesh Chaudhry. (2006). The impact of mean reversion of bank profitability on post-merger performance in the banking industry. Journal of Banking \& Finance, Vol. 30, Issn.12, p. 3503 p. 236. 